\title{
Fundamental patents, national intellectual property regimes, and the development of new industries in Britain and America during the second industrial revolution
}

Article

Accepted Version

Scott, P. and Spadavecchia, A. (2019) Fundamental patents, national intellectual property regimes, and the development of new industries in Britain and America during the second industrial revolution. Economic History Yearbook, 60 (1). pp. 181-208. ISSN 0075-2800 doi: https://doi.org/10.1515/jbwg2019-0008 Available at https://centaur.reading.ac.uk/79610/

It is advisable to refer to the publisher's version if you intend to cite from the work. See Guidance on citing.

To link to this article DOI: http://dx.doi.org/10.1515/jbwg-2019-0008

Publisher: Verlag De Gruyter

All outputs in CentAUR are protected by Intellectual Property Rights law, including copyright law. Copyright and IPR is retained by the creators or other copyright holders. Terms and conditions for use of this material are defined in the End User Agreement. 


\section{CentAUR}

Central Archive at the University of Reading

Reading's research outputs online 


\title{
Fundamental patents, national intellectual property regimes, and the development of
} new industries in Britain and America during the second industrial revolution

\author{
Peter Scott \\ Henley Business School, University of Reading \\ Anna Spadavecchia \\ Henley Business School, University of Reading
}

\begin{abstract}
Several "new" industries of the second industrial revolution were characterised by one, or few, "fundamental" patents, without which manufacture of a viable product was not practicable. The degree of monopoly control that such patents conveyed was mediated by national socio-legal regimes, encompassing both patent law and its interpretation and enforcement. Using four case-studies (two for the UK - a low antitrust environment, and two for the USA - a high anti-trust environment) we show that fundamental patents were major determinants of monopoly power, industry structure, barriers to competition, and consumer prices. Impacts could extend beyond the life of the patents, owing to first mover advantages and path-dependent processes. Meanwhile national socio-legal environments, the nature of the fundamental patents, the strategies of the patent owners, and the nature of the specific product technology could have important (and sometimes unforeseen) consequences.
\end{abstract}

JEL codes: N70, 031, 032, 033, 034, 038

Key words: fundamental patents; barriers to competition; anti-trust; intellectual property; patent regulation. 


\section{Biographical notes}

Peter Scott is Professor of International Business History at the University of Reading's Henley Business School. His research encompasses industrial evolution; path dependence; consumption; and consumer goods. His most recent (2017) Oxford University Press monograph, The Market Makers. Creating Mass Markets for Consumer Durables in Inter-War Britain, explores the factors influencing the early development of Britain's consumer durables' sectors, including the role of patents.

Anna Spadavecchia is Associate Professor at the University of Reading's Henley Business School. Her research encompasses the development of clusters in the $20^{\text {th }}$ century; regional innovation in Britain; innovation and the Italian economic performance in the long run. Her publications include book chapters for Oxford University Press and Boydell Press as well as

articles in Business History, The Economic History Review, Enterprise and Society and Oxford Economic Papers. 
The period from around 1860 to 1914 saw the launch of a cluster of "new" industries, mainly based on the technologies of electricity, the internal combustion engine, and new developments in industrial chemistry. Several were characterised by one, or few, "fundamental" patents, without which manufacture of a viable product was not practicable. Such patents were of considerable importance to the development of many new industries of the "second industrial revolution", including electrical goods and power, communications, sound recording, film, chemicals, bicycles, automobiles, and aircraft. ${ }^{1}$ This process was in turn mediated by national socio-legal regimes - encompassing patent law; the interpretation of the law by the courts; non-patent legislation or pressure (such as anti-trust law and nationalistic sentiment); and the ability of vested interests to sway the outcome of legal challenges - for instance through buying up the best legal expertise or having sufficient capital to engage in protracted litigation. Such factors could potentially lead to very different outcomes for the same companies in different jurisdictions.

The importance of fundamental patents is emphasised in the literatures on patent law and competition policy, which note the growing importance and potential monopoly power implications of such patents, in the context of current new technologies such as biotech and semiconductors. ${ }^{2}$ It is also beginning to be explored in the economic history literature. For example, Christopher Beauchamp has shown how, during the second industrial revolution, courts and law suits moved to the centre of inter-firm relations in a range of new industries, influencing both the extent to which patents on basic innovations were interpreted narrowly

\footnotetext{
${ }^{1}$ C. Beauchamp, The Telephone Patents: Intellectual Property, Business, and the Law in the United States and Britain, 1876-1900, in: Enterprise \& Society 9, 2008, pp. 591-601, p. 593.

${ }^{2}$ See, for example, J.H. Barton, Patents and Antitrust: a Rethinking in Light of Patent Breadth and Sequential Innovation, in: Antitrust Law Journal 65, 1997, pp. 449-66.
} 
or broadly and whether the potential for monopoly power inherent in patents was translated into real monopoly control. ${ }^{3}$

In this article we explore the importance of fundamental patents to the development of the new industries of the early twentieth century. Using case-studies we show that fundamental patents were major determinants of monopoly power, industry structure, barriers to competition, and consumer prices, in these industries. Patent licensing agreements constituted powerful instruments of control, which could be used to influence not only costs, but prices, product characteristics, tied purchases, and the extent of inter-industry competition. Their impacts could extend beyond the life of the patents, owing to first mover advantages and path-dependent processes. Meanwhile national socio-legal environments, the nature of the fundamental patents, the strategies of the patent owners, and the specific product technology could also have important (and sometimes unforeseen) consequences.

We focus on two national cases, Britain and the USA. Britain had a particularly strong intellectual property regime, stemming from what Nigel Harris has characterised as a "liberal-conservative political economy" developed to serve what was primarily a financial and mercantile economic elite. Victorian Britain developed a consensus based around free trade, freedom of contract, and business self-regulation. ${ }^{4}$ This was reflected in court decisions that increasingly emphasised property rights and avoiding state 'interference' in private property; progressively marginalising an older tradition of British common law that was antagonistic to 'restraints of trade'. ${ }^{5}$ Moreover, in contrast to the United States, Britain had no

\footnotetext{
${ }^{3}$ Beauchamp, The Telephone Patents.

${ }^{4}$ T. Freyer, Regulating Big Business: Antitrust in Great Britain and America, 1880-1990, Cambridge 1992, p. 8.

${ }^{5}$ N. Harris, Competition and the Corporate Society. British Conservatives, the State and Industry 1945-1964, London 1972, p. 25; L. Hannah, The Rise of the Corporate Economy, London 1976, pp. 42-3.
} 
anti-trust legislation to temper the potential welfare losses arising from the un-restricted exploitation of patent monopolies until after the Second World War. ${ }^{6}$

In contrast, American political economy increasingly reflected fears regarding potential abuses of monopoly power. The 1890 Sherman Anti-trust Act prohibited individual or collective actions aimed at creating monopoly positions. Toney Freyer has identified a trend from the 1890s for American courts to became more hostile towards anti-competitive agreements; in contrast to British courts, which were increasingly prepared to not only permit, but to enforce, such agreements. ${ }^{7}$ In 1914 the Federal Trade Commission Act and the Clayton Act substantially strengthened the effectiveness of U.S. anti-trust policy, by empowering the Trade Commission to investigate restrictive practices which might violate the Sherman Act and to enforce prohibitions against them. ${ }^{8}$ The inter-war period saw a general rise in anti-trust sentiment (though the priority given to anti-trust enforcement ebbed and flowed, according to the economic cycle and other factors), which further tempered the potential monopoly power of fundamental patent ownership, as discussed in the U.S radio case below.

This study examines two types of patents where the potential for control extends beyond the specific patented item. The first - 'discrete' patents - cover components which are essential to manufacturing viable products, but which are not the focus of cumulative

\footnotetext{
${ }^{6}$ For a discussion of the interaction of patent and anti-trust legislation, see L. Kaplow, The Patent-antitrust Intersection: a Reappraisal, in: Harvard Law Review 97, 1984, pp. 1813-92; M. A. Carrier, Unravelling the Patent-antitrust Paradox, in: University of Pennsyslvania Law Review 150, 2002, pp. 761-854.

7 Freyer, Regulating Big Business, pp. 24 \& 78-9.

${ }^{8}$ S.N. Broadberry/ N F.R. Crafts, Britain's Productivity Gap in the 1930s: Some Neglected Factors, in: The Journal of Economic History 52, 1992, pp. 531-558, p. 547.
} 
innovation for those products. We explore one UK case, the carbon light bulb filament, and one U.S. case, the Kenney patent on using a narrow aperture of a larger tube to create a powerful vacuum. Both of these were introduced prior to the First World War, when U.S. anti-trust pressure was still relatively weak and both had the effect of restricting competition and raising prices (though differences in patent exploitation strategies led to the creation of a simple monopoly in the first case and an exclusive cartel in the second).

The next two cases involve fundamental patents which formed the base of a cumulative process of innovation, with improvements to the technology generally building directly on early patents (unlike, for example, the tungsten light filament, which displaced, rather than improved, the carbon filament). Such patents are common in many electromechanical sectors, such as automobiles, aircraft, and, later, semiconductors and computer hardware and software. In such industries an uncompromising approach to prioritising patent rights is viewed as particularly problematic for post-patent innovation compared to an `open marketplace' for improvements on initial patents. ${ }^{9} \mathrm{We}$ look at a technology that was commercially exploited from the early 1920 s - entertainment radio in the USA and in the UK. Here differences in national intellectual property and anti-trust regimes are shown to have had fundamental impacts on costs and 'rents' in the sector - despite the fact that patent licenses were available to all complying manufacturers in both countries.

\section{The incandescent lightbulb}

Interest in incandescent lighting began in the early $19^{\text {th }}$ century in Britain. The first British patent on an incandescent lamp was granted in 1841 to the Englishman Frederick De

\footnotetext{
${ }^{9}$ Kaplow, The Patent-antitrust Intersection; Carrier, Unravelling the Patent-antitrust, pp. 829-31.
} 
Moleyns. Then, in 1845, American inventor, J.W. Starr filed a British patent for an incandescent lamp composed of a carbon rod in a vacuum above a column of mercury. Two major technical problems - creating a vacuum in the lamp in order to extend the life of the incandescent material and securing a reliable source of electricity - were addressed in the 1860s and 1870s, leaving the development of a satisfactory illuminant as the last important obstacle to a commercially viable incandescent lightbulb. Experiments were conducted using various metals, and carbon proved the most suitable material because its melting point is higher than that of any metal and its resistance to electric current is appropriately high. ${ }^{10}$

Sawyer and Man filed a U.S. patent for a "nitrogen-filled lamp employing a carbon rod as the illuminant" in January 1879, which their agent had earlier patented in England. ${ }^{11}$ Thomas Edison experimented with high-resistance carbon filament conductors, including carbonised cotton sewing thread, carbonised Bristol-board filaments, and bamboo filaments. His cotton thread patent (No. 223,898) proved to be the basic patent in the early American incandescent-lamp industry. The innovative feature was a high-resistance carbon conductor illuminant in filamentary form, which had only been used in the unauthenticated Göbel lamp of 1854. The distinction between a carbon rod and a carbon filament provided the basis for Edison's patent as well as for his commercial success. ${ }^{12}$

Edison followed a systematic policy of international patenting, using patents with broad claims, to maintain control over his inventions and block the entry of competitors. ${ }^{13}$ In

\footnotetext{
${ }^{10}$ A. A. Bright, The Electric-Lamp Industry. Technological Change and Economic Development from 1800 to 1947, New York 1949, pp. 35-41.

${ }^{11}$ Bright, The Electric-Lamp, pp. 51-52.

${ }^{12}$ Bright, The Electric-Lamp, p. 42; M. A. Lemley, The Myth of the Sole Inventor, in: Michigan Law Review 110, 2012, pp. 709-760.

${ }^{13}$ S. Sell, Intellectual Property and Public Policy in Historical Perspective: Contestation and Settlement, in: Loyola of Los Angeles Law Review 38, 2004, pp. 267-321.
} 
1879, in keeping with this strategy, Edison filed patents for his carbon filament and easily obtained a British patent - in contrast to the USA, where, after a five year struggle, Sawyer and Man managed to prove "priority of reduction to practice" for their incandescent lamps. ${ }^{14}$ However, in Britain Joseph Swan had been experimenting with the incandescence of carbonised paper coils in a vacuum since 1848 and resumed his experiments in the late 1870s, as the vacuum problem was now solved. Swan and his team managed to develop and demonstrate the first carbon-filament lamp between December 1878 and the early months of 1879, but did not file a patent until Swan became aware of Edison's patenting. ${ }^{15}$ Meanwhile St. George Lane-Fox patented a process for creating a uniform resistance filament by carbonising a French grass fibre in 1879, which he sold to the Anglo-American Brush Electric Light Corporation. ${ }^{16}$

The British Edison Company was established in 1882 to develop and control the British electric lighting market using the Edison patent. It commenced legal action against the Swan Company for patent infringement, but, mindful of Swan's evidence of prior research and publication, switched to negotiating a merger deal that created the Edison and Swan United Electric Lighting Company (later, the Edison and Swan Electric Lighting Company) to exploit Edison and Swan's complementary patents, together with Gimingham's British patent (UK 4193, 1881) and the Cheesborough patent (1878). ${ }^{17}$ This created a monopoly position that lasted until Edison's patent expired in $1893 .{ }^{18}$

\footnotetext{
${ }^{14}$ Bright, The Electric-Lamp.

${ }^{15}$ S. Arapostathis/G. Gooday, Patently Contestable. Electrical Technologies and Inventor Identities on Trial in Britain, Cambridge Mass. 2013, pp. 177-179.

${ }^{16}$ Bright, The Electric-Lamp, pp. 49-50.

${ }^{17}$ The Manchester Guardian, October $3^{\text {rd }} 1883$; Arapostathis/Gooday, Patently Contestable, p. 185.

${ }^{18}$ Arapostathis/Gooday, Patently Contestable, pp. 183-184.
} 
The newly established company protected its position through legal actions, in line with Edison's strategy of 'predatory patenting'. Between 1885 and 1901, the Edison Company filed over two hundred infringement suits and its expenses for litigation amounted to $\$ 2$ million. ${ }^{19}$ Among various British court cases, the actions brought against Woodhouse \& Rawson in 1884 and 1885, Holland in 1885, and subsequent appeals, were widely publicised. After the court's decision to uphold Edison's patents against Woodhouse \& Rawson, it became apparent that the Edison and Swan Co. was trying to establish a monopoly. Manufacturers reacted by establishing a committee to monitor Edison and Swan, while unsuccessfully lobbying for Parliamentary intervention. ${ }^{20}$

Edison and Swan also sued light bulb suppliers and users, including the manager of the Albert Palace at Battersea, for infringing their patents. The defendants attacked Edison's patent on the grounds of its broad claims and insufficient disclosure of details. After hearing expert witnesses and a moderator's report, the judge decided in favour of Edison and Swan as far as the Cheesborough patent was concerned. However, he also concluded that the Edison patent was invalid because its claims were too broad and it did not disclose sufficient information about manufacturing a carbon filament. Edison and Swan appealed against the latter decision and, in 1889, won their appeal against Holland, Jablochkoff Electric Light \& Power Company, and General Electricity Ltd, who had supplied the lamps, and against the Anglo-American Brush Electric Light Company, the manufacturers of the lamps - who took up the defence. The judges of the Appeal case considered Edison's filament patent as a "new

\footnotetext{
${ }^{19}$ Sell, Intellectual Property, p.298.

${ }^{20}$ Chancery Division/1886/Volume 32/Edison and Swan Electric Light Company v. Woodhouse [1884. E. 89.]

(1886) 32 Ch.D. 520; Incandescent Lamps, in: The Times, August $27^{\text {th }} 1886$, p. 3.
} 
departure in electricity, that the specification sufficiently describes and ascertains the nature of the invention." 21

These legal victories gave Edison and Swan an effective monopoly, enabling them to charge very high prices during the lifetime of the patent. ${ }^{22}$ For example, a 16-candlepower lamp, priced at 3 shillings 9 pence in Britain, could be obtained in continental Europe for only 1 shilling. ${ }^{23}$ Edison-Swan and Anglo-American Brush Electric became the major players in the British light-bulb industry, which by 1893 , included only seven manufacturers. A large number of other concerns, 48 by 1893 , confined themselves to arc lighting after the Edison and Swan v. Holland court case.

\section{[Figure 1 near here]}

The monopolistic position of the Edison and Swan Company ended with the expiry of Edison's fundamental patent in 1893. Thereafter the number of light bulb manufacturers increased to 24 (see Figure 1), which was still well below the 51 manufacturers of arc lights. Bright mentions that 50 new brands, some of which foreign, were introduced in Britain between 1893 and 1896. However, several newly-established manufacturers proved shortlived and Edison and Swan sustained its leading position, based on important continuing patents on lamp holdings and fittings, together with its strong brand and highly developed distribution system. ${ }^{24}$

\footnotetext{
${ }^{21}$ Incandescent Lamps, in: The Times, August 27 $7^{\text {th }}$ 1886; Edison and Swan United Electric Company v. Holland in: The Times, December $14^{\text {th }} 1888$; Law Report, February $18^{\text {th }} 1989$, Supreme Court of Judicature Court of Appeal Edison and Swan United Electric Light Company v. Holland, in: The Times, February $19^{\text {th }} 1989$; Arapostathis/Gooday, Patently Contestable, pp. 185-190; Bright, Electric-Lamp, p. 108.

${ }^{22}$ Electrician 17, 1886, p. 50, cited in Arapostathis/Gooday, Patently Contestable, p. 185; J. Swinburne, The Edison Filament Case, in: The Telegraphic Journal \& Electrical Review, August 6 ${ }^{\text {th }} 1886$, pp. 129-134.

${ }^{23}$ Bright, Electric-Lamp, p. 109.

${ }^{24}$ Bright, Electric-lamp, p. 109.
} 
Competition led to price reductions; the prices of standard 8- and 32-candlepower lamps dropped to about a shilling, partly owing to cheaper German imports, which had been previously blocked from the British market by the patents and against which British firms struggled to compete. ${ }^{25}$ As a Parliamentary subcommittee noted, foreign industries that had been free from patent restrictions, as in Germany where the claims of Edison's patents were narrower, had progressed more rapidly in terms of manufacture techniques and industry organisation. $^{26}$

High prices retarded the diffusion of electric lighting (and, therefore, electrification) in Britain, a problem compounded by The 1882 Electric Lighting Act. Designed to prevent a recurrence of earlier monopoly power abuse by gas supply companies, the Act empowered local authorities to purchase companies licensed to supply electric current and lighting, at a fair market value, within six months after 21 years from the date of the license. The risk of having to sell their investments at "asset value" after only 21 years acted to deter private investors, until the law was amended in 1888 , extending the period to 42 years. ${ }^{27}$

Even after the expiration of the Edison patent the sector continued to be characterised by restrictive practices, underpinned by patent control. The British Carbon Lamp Association was established by British manufacturers in 1905, to control the price of carbon filament lamps. This involved the creation of a patent pool, together with the acquisition of foreign

\footnotetext{
${ }^{25}$ Profiteering Act, 1919, Findings and Decisions of a Sub-committee appointed by the Standing Committee on Trusts, to Enquire into the Existence of any Trust of Trade Combination in the Electric Lamp Industry, 1920, National Archives BT 55/55.

${ }^{26}$ Profiteering Act, 1919, Findings and Decisions; J. M. Rees, Trusts in British Industry 1914-1921. A Study of Recent Developments in Business Organisation, London 1922, p. 212; R. Cullis, What Makes a Successful Innovation? Four Inventions which Changed the World Economy, e-book 2008, p. 166.

${ }^{27}$ R. Fitzgerald, International Business and the Development of British Electrical Manufacturing, 1886-1929, in: Business History Review 91, 2017, pp. 31-70.
} 
patents including that for the 'squirted tungsten filament', granted to the Austrian inventors Alexander Just and Franz Hannan in 1904, for which General Electric Co. Ltd. succeeded in acquiring the British rights. ${ }^{28}$ Overlapping patents for the new Tungston filament technology risked costly litigation, which was avoided by the British Thomson-Houston Co. (the majority shareholder of which was the General Electric Company), the Osram Lamp Works Ltd (at the time a subsidiary of the General Electric Company specialised in tungstenfilament lamps) and later Siemens deciding to "come together, primarily on patents, each agreeing to recognise the others' patents and to license the others for its own patents, and to interchange factory and laboratory experience". ${ }^{29}$ The three corporations, together with Edison and Swan Electric Co., formed the Tungsten Lamp Association in 1912, creating a patent pool and agreeing to license their patents to other British lamp manufacturers - again with the objective of exerting control over the industry. ${ }^{30}$ The Tungsten Lamp Association was incorporated as the Electric Lamp Manufacturers' Association of Great Britain, Ltd., in April 1919. ${ }^{31}$

\section{[Table 1 near here]}

The cartel controlled 85 percent of British production just prior to the First World War, rising to 95 percent by the end of the War, and had succeeded in "protecting" the British market from overseas competition via its patent monopoly. ${ }^{32}$ Table 1 shows the higher prices

\footnotetext{
${ }^{28}$ Standing Committee on Trusts, Fifth Meeting, January $13^{\text {th }} 1920$, National Archives BT 55/55; Profiteering Act, 1919, Electric Lamps, Finding and Decisions of a Sub-Committee Appointed by the Standing Committee on Trusts, Draft Report, National Archives BT 55/55; Bright, Electric-Lamp, p. 163.

${ }^{29}$ Standing Committee on Trusts, Fifth Meeting, January $13^{\text {th }} 1920$, National Archives BT 55/55; Bright,
} Electric-Lamp, p. 162.

${ }^{30}$ Arapostathis/Gooday, Patently Contestable, p. 194.

${ }^{31}$ Standing Committee on Trusts, Fifth Meeting, March $9^{\text {th }}$ 1920, National Archives BT 55/55.

${ }^{32}$ Rees, Trusts, pp. 211-217; Arapostathis/Gooday, Patently Contestable, pp. 194-195. 
imposed by the Association compared to non-Association manufacturers. Control was exerted through a system of incentives (discounts) and penalties (loss of discount and "blacklisting") for distributors who sold bulbs produced outside the Association, together with other tactics aimed at reducing the competitive position of outsiders. The Association's leading firms also used their patents to reduce competition from within the cartel, through restrictive patent licenses that limited the output of licensees and stipulated that the validity of their patents should not be disputed. ${ }^{33}$ Thus Britain continued to face higher lighting prices, slowing the diffusion of electrification, into the 1920 s.

\section{The vacuum cleaner}

The vacuum cleaner provides a classic example of a simple, "broad", patent essential to the development of a viable product. Despite a variety of earlier patents, British fairground engineer Hubert Cecil Booth is generally credited with inventing the powered vacuum cleaner, in 1901, in the shape of a huge petrol-powered machine, pulled by horses. ${ }^{34}$ However, the fundamental patent proved to be that of American inventor David T. Kenney a sanitary engineer, who had already successfully patented a toilet flush mechanism. ${ }^{35}$ In November 1901 (nine months after Booth's patent application), Kenney filed a U.S. patent for an 'apparatus for removing dust' which was granted in 1907 (\#847,947, 19 ${ }^{\text {th }}$ March 1907), followed by further patents for refinements such as improved nozzles, cleaning tools for

\footnotetext{
${ }^{33}$ Profiteering Act, 1919, Findings and Decisions.

${ }^{34}$ C. Gantz, The Vacuum Cleaner. A History, Jefferson N.C. 2012, p. 35; J. Furnival, Suck, Don’t Blow, London, 1998, pp. 10-11.

${ }^{35}$ M. Robinson Sive, Vacuum Cleaners Before Electricity, in: Historical Text Archive, https://historicaltextarchive.com/sections.php?action=read\&artid=769 , accessed $12^{\text {th }}$ March 2018.
} 
uneven surfaces, and a system for trapping the collected dust in water. ${ }^{36}$ Kenney's 1901 patent was the first to use a vacuum as the sole cleaning method, while Kenney avoided litigation with Booth by purchasing his U.S. patent application. This case-study focuses on the exploitation of the Kenney patent within the USA, as North America was one of the very few markets where a substantial vacuum cleaner industry emerged within the patent's lifetime.

Kenney's original application covered the essential principle of all vacuum cleaners, the 'narrow nozzle' - sucking air through a narrow section of a broader tube to create a powerful vacuum that would draw in dirt. The patent-holding company, the Vacuum Cleaner Company of New York, was successful in having this patent held valid and infringed in 1907 and by 1909 had given up manufacturing in favour of granting licenses to independent manufacturers. ${ }^{37}$ In 1911 four leading manufacturers formed a defence association to fight the Kenney patents. Following negotiations, in June 1912 they accepted Kenney licenses on a 2.5 per cent royalty basis. This later evolved into a trade association, the Vacuum Cleaner Manufacturers Association (VCMA), with membership restricted to Kenney patent licensees..$^{38}$

The VCMA played a major role in determining the structure of the licensing system. Clause Seven of the Kenney license stated that the licensor would not grant further licenses without the consent of three quarters of existing licensees. The Kenney patents' trustee explained the rationale to the Federal Trade Commission (FTC) as follows: 'When the licensees got that contract they got it for the purpose of holding me down and keeping

\footnotetext{
${ }^{36}$ Robinson Sive, Vacuum Cleaners.

${ }^{37}$ Gantz, Vacuum Cleaner, pp. 49-52.

${ }^{38}$ Kenney license contract of 1912, reproduced in Federal Trade Commission, Report on the House Furnishings Industry. Volume III: Kitchen Furnishings and Domestic Appliances, Washington 1925, p. 276.
} 
everybody out of the business. ${ }^{39}$ Indeed it was the policing of this provision that was the VCMA's principal function. Moreover clause 14 of the Kenney license stated that licenses were not assignable to other parties by the licensee, unless the firm in question was to take over its entire vacuum business. ${ }^{40}$ One immediate impact was that a Kenney license became a valuable asset. For example, Hoover Co. bought a Kenny license from the Vacuum Cleaner Company of New York, but was so concerned that this might be declared invalid (given that Clause Seven prohibited further licensing) that it went to the additional expense of buying out the Palm Vacuum Cleaner Co., who held an original Kenney license. ${ }^{41}$

A similar situation arose in the U.S. automobile industry, where the Selden patent was successfully filed for a basic automobile configuration, using a lightweight internal combustion engine. Like the Kenney patent the key insight (in this case that a light, powerful, engine was critical to developing a viable automobile) was already known to others working in the field. Indeed the success of both patents may owe much to the fact that incumbent manufacturers supported them as vehicles to exclude further entry into the sector. ${ }^{42}$

The Kenney licensing system, managed by the VCMA and the patent holder, fostered an industry structure based on very strong barriers to entry; high, relatively stable, prices; and a considerable degree of co-operation between member companies. By March 1924 (when the patent expired) there were 19 direct licensees and 6 sub-licensees, all of whom were

\footnotetext{
${ }^{39}$ Federal Trade Commission, Report on the House Furnishings Industry, p. 7.

${ }^{40}$ Kenney license contract of 1912, reproduced in Federal Trade Commission, Report on the House Furnishings Industry, p. 278.

${ }^{41}$ Gantz, The Vacuum Cleaner, pp. 66-67.

${ }^{42}$ R.P. Merges/R.R. Nelson, Market structure and technical advance: the role of patent scope decisions, pp. $185-$ 232, in: T.M. Jorde/D.J. Teece (Ed.), Antitrust, Innovation, and Competitiveness, New York 1992, p. 205.
} 
VCMA members, encompassing all significant U.S. manufacturers. ${ }^{43}$ Restricting competition proved highly lucrative; the FTC found that profit rates for the vacuum cleaner sector were considerably higher than for ten other consumer durables' sectors it examined, partly owing to the use of the Kenney patent to block market entry. Rates of return on initial investment in 1920 were found to average 44.1 per cent, compared to rates for other household durables varying from 3.6 per cent (brooms) to 28.2 per cent (furniture); while in 1921 (a recession year) they were more than double that of the next most profitable sector. ${ }^{44}$ The FTC attributed vacuum manufacturers' much larger profits to their ability to maintain prices, even during demand slumps.

The VCMA encouraged co-operation between licensees, reflected in industry characteristics typical of cartels - including an emphasis on non-price competition. The system also fostered high levels of patenting by Kenney licensees, so that individual firms could trump proprietary features exclusive to their particular brand. By May 1922 firms in the sector collectively held over 275 patents. ${ }^{45}$ However, rather than being improvements to the Kenney patent, these typically involved other components of the vacuum cleaner, and - while some were important - none were fundamental to developing a commercially viable cleaner. For example, Hoover filed a patent in September 1910 - for 'carpet agitation' - via a motordriven rotary brush that produced a beating action as it passed over the carpet. ${ }^{46}$ This gave

\footnotetext{
${ }^{43}$ Federal Trade Commission, Report on the House Furnishings Industry, p. xix; Gantz, Vacuum Cleaner, p. 92.

${ }^{44}$ Federal Trade Commission, Report on the House Furnishings Industry, pp. xx-xxi \& 18.

${ }^{45}$ VCMA minutes, $28^{\text {th }}$ October 1921, cited in Federal Trade Commission, Report on the House Furnishings Industry, pp. 10-11.

${ }^{46}$ Ibid, pp. 53-67.
} 
Hoover a competitive advantage, through preventing other firms copying this particular system, until $1926 .^{47}$

The emphasis on patented 'features' as a source of firm-level product differentiation (often more important to marketing claims than to the basic functionality of the cleaner) may also explain why VCMA negotiations in 1921 to create a pool of its members' patents - and thereby extend VCMA control beyond the lifetime of the Kenney patent, were unsuccessful (though anti-trust fears may have also been important). The VCMA did, however, continue after the Kenney patent expired, fostering co-operation in the standardisation of parts and accessories and the compilation of sales statistics. ${ }^{48}$

The restriction of competition arising from the Kenney patent fostered a concentrated, collusive, industry, with an emphasis on non-price competition. For example the market leader, Hoover, had the highest list prices of any significant manufacturer, which were vigorously enforced. ${ }^{49}$ Table 2 shows costs and profits for 11 companies (including all significant manufacturers in the sector), for 1920 and 1921, classified by value of invested capital. ${ }^{50}$ Large firms appear to have used lower unit production costs to gain market share through lavish selling expenses (which rose from 6.3 per cent of net sales for the smallest class of firms to 25.7 per cent for the largest class in 1920). Much of this money went on

\footnotetext{
${ }^{47}$ Ibid, p. 96.

${ }^{48}$ Ibid, pp. 9-14.

${ }^{49}$ Gantz, The Vacuum Cleaner, p. 98.

${ }^{50}$ VCMA minutes, 28 ${ }^{\text {th }}$ October 1921, cited in Federal Trade Commission, Report on the House Furnishings Industry, p. 18.
} 
raising and deploying armies of door-to-door salesmen, which constituted an expensive, but effective, means of promoting this new product. ${ }^{51}$

\section{[Table 2 near here]}

The Kenney patent had enabled incumbent vacuum manufacturers to maintain control over their sector for several decades, via a licensing system that offered many of the barriers to entry advantages of trusts, without blatantly flouting what was, in other respects, relatively strong U.S. anti-trust legislation. The vacuum sector retained its stable and relatively concentrated industry structure (compared to most electrical consumer durables) until the late 1930s and continued to be characterised by a high degree of price stability. Almost all the major U.S. vacuum cleaner manufacturers were founded during the lifetime of the Kenney patent (generally during its first decade) and by the time the patent expired they had developed strong first mover advantages, in terms of patents, cumulative investment in brands, and nationwide door-to-door sales forces, that were particularly important in a sector characterised by high consumer inertia and products that lent themselves to selling via demonstration. The main exception was Electrolux, which had developed similar proprietary assets in Sweden, that were transferred to the USA with the opening of a sales subsidiary in 1924 (the year the Kenney patent expired) and a U.S. factory in $1933 .{ }^{52}$

\section{Radio patents in a high anti-trust environment: the USA}

\footnotetext{
${ }^{51}$ P. Scott, The Market Makers. Creating Mass Markets for Consumer Durables in Inter-war Britain, Oxford 2017, pp. 217-225.

${ }^{52}$ P. Scott, The organizational salesman: managerial homogeneity, organizational commitment strategies, and institutional rigidity in the inter-war U.S. vacuum cleaner sector, unpublished paper, 2018.
} 
Industries such as electronics, motor vehicles, and aircraft (and, later, semiconductors and computer hardware and software) are typically subject to a process of cumulative technological advance, rather than the 'discrete', one-off, innovations that characterise much of the standard invention literature. They are also typically characterised by complex systems made up of many components, with technological progress taking place on a number of fronts simultaneously, within a common technological standard. ${ }^{53}$ Thus the holder of a fundamental patent on a component which is essential to producing a viable product is in a position to block innovations directly building on that patent, or those involving other components that cannot be used without the component covered by the fundamental patent.

"Broad" fundamental patents (with applications beyond a single narrow product) can thus influence the pace and nature of follow-on research, even potentially blocking such research. The holder of the narrower ('subservient') patent cannot utilise their improvement without a license from the holder of the fundamental ('dominant') patent. Similarly, the holder of the dominant patent cannot utilise the improvement claimed in the patent without a license from its owner. ${ }^{54}$ On the other hand they can be used to create potential monopoly positions over product categories, either for a single firm or through cross-licensing agreements that effectively exclude 'outsiders'. ${ }^{55}$ We provide two case-studies for radio, covering the United States and Britain, to illustrate the crucial role of anti-trust policy in mitigating the potential welfare losses arising from the monopoly power that control over fundamental patents can provide in these circumstances.

\footnotetext{
${ }^{53}$ Merges/Nelson, Market Structure, pp. 202-203; Kaplow, The Patent-antitrust Intersection; Carrier, Unravelling the Patent-antitrust, pp. 829-31.

${ }^{54}$ Merges/Nelson, Market Structure p. 195.

${ }^{55}$ See, for example, Barton, Patents and Antitrust.
} 
Numerous individuals and firms contributed to the development of speech radio. The most important single innovator, however, was Guglielmo Marconi (1874-1937), an Italian who spent most of his working life in Britain. Marconi Co. established an American subsidiary in 1899 , to lease equipment for maritime communications, and subsequently took out various U.S. patents, including for the 'diode' (the basic version of the thermionic tube, invented by Ambrose Fleming). The diode magnified radio signals using a two element thermionic tube, which was improved on in 1907 by Lee de Forest's addition of a third element (the triode), making it a much more sensitive and powerful radio wave amplifier and detector. The triode proved the key component for clear radio reception and transmission, leading Western Electric (a subsidiary of American Telegraph \& Telephone Co. (AT\&T)) to purchase the patent, which they transformed into a much more powerful device through intensive R\&D. ${ }^{56}$

Subsequent innovation was hampered by patent litigation. For example in 1915 Marconi sued de Forest, claiming that the triode infringed the diode patent. De Forest counter-sued (as Marconi had added a third element to some of its tubes, infringing the triode patent), with the result that each party was found to have infringed the other. ${ }^{57}$ This effectively blocked the use of the triode pending successful negotiations.

Parchomovsky and Wagner have discussed how a portfolio of closely related patents can act as a "super patent", conferring similar market power to that of a single broad fundamental patent. This provides a variety of advantages, including reducing patent litigation (both defensively and as a potential infringer - for example by having credible counter-claims for infringement). Fundamental patents are of crucial importance to such

\footnotetext{
${ }^{56}$ L.S. Reich, Research, Patents, and the Struggle to Control Radio: A Study of Big Business and the Uses of Industrial Research, Business History Review 51, 1977, pp. 208-235, pp. 211-213.

${ }^{57}$ Reich, Research, Patents, pp. 215-16.
} 
portfolios, 'anchoring' the overall portfolio and often denying competitors access to elements that are vital to the creation of a viable device. ${ }^{58}$

Following the predictions of this model, GE, AT\&T, and Westinghouse engaged in a race to develop radio patents. Then in April 1917 America's entry into the First World War led to a temporary moratorium on patent litigation, giving all parties freedom to innovate. The U.S. Navy thereafter sought to create a permanent solution to the domination of American wireless communications by a 'foreign' company (Marconi's American subsidiary), which refused to sell its patented equipment outright, by unifying all U.S. radio patents in a single national champion. The Navy's intervention led to the launch of Radio Corporation of America (RCA) as a sales company to market radios produced by the two main U.S.-based patent holders: GE (producing 60 percent of its sets) and Westinghouse who controlled the patents for two key radio circuits, the heterodyne and super-heterodyne (40 per cent). ${ }^{59}$ Meanwhile AT\&T gained protection for its monopoly position in telephone communications. Marconi also came out well from the deal, which involved an exchange of all patent rights between them and RCA, both for current patents and any future ones, up to 1945, giving Marconi access to a research stream that it would have found hard to replicate in its own laboratories. ${ }^{60}$

RCA thus held a monopoly of both fundamental radio patents and of those improvement patents that could potentially block their transformation into practicable and efficient devices. These were to be exploited via its own sales monopoly in conjunction with

\footnotetext{
${ }^{58}$ G. Parchomovsky / R. Polk Wagner, Patent Portfolios, in: University of Pennsylvania Law Review 154, 2005, pp. 1-77, pp. 31-36.

${ }^{59}$ W. Rupert Maclaurin, Invention and Innovation, New York 1949, p. 107; R. Sobel, RCA, New York 1986, pp. 21-35; Reich, Research, Patents, pp. 217-20.

${ }^{60}$ Reich, Research, Patents, p. 217.
} 
a production monopoly for GE and Westinghouse. However, this combine failed to keep up with the explosive growth of demand for entertainment radio. The proportion of American households with radios rose from less than 1 per cent in 1922 to 16.0 per cent in 1926, and 45.8 per cent in $1930 .{ }^{61}$ RCA produced insufficient sets to service this market, partly owing to delays in getting agreement on set specifications between RCA's sales department and the two manufacturing companies. These problems proved so severe that some small firms that had obtained 'amateur set' licenses from Edwin Armstrong before he had sold his patents to Westinghouse were able to not only undercut RCA's price structure but also beat them to the market with technical improvements (essentially minor innovations within the existing technological standard).

Moreover, de Forest, who had retained a triode license for his own use, was able to sell triodes in competition with RCA following the termination of the diode patent in 1922 . This enabled competitors to produce radios using circuits RCA did not control, particularly the neutrodyne. RCA sued for patent infringement, on the basis that the neutordyne was an improvement on RCA patented technology, but the case was not finally decided in its favour until $1927 .{ }^{62}$ RCA also faced continuing technical problems and product launch delays, including being forced to release their first superheterodyne radio late and with an unresolved thermal-hiss problem; subsequent problems of factory quality control and engineering design; a consequent build-up of obsolescent stock; and delays in launching new models. ${ }^{63}$

\footnotetext{
${ }^{61}$ S.B. Carter / S.S. Gartner / M.R. Haines / A.L. Olmstead / R. Sutch / G. Wright (Ed.), Historical Statistics of the United States. Earliest Times to the Present. Millennial Edition, Cambridge 2006, Vol. 1, p. 667; Vol. 4, p. 1027.

${ }^{62}$ Reich, Research, Patents, pp. 225-7.

${ }^{63}$ A.Douglas, Radio Manufacturers of the 1920's. Vol. 3. RCA to Zenith, New York 1991, pp. 29-43.
} 
RCA consequently gained less than a quarter of the receiver market during 192227. ${ }^{64}$ Meanwhile judicial interpretations of America's strong anti-trust legislation, designed to curb abuses of monopoly power, increasingly undermined RCA's ability to leverage its monopoly position. For example, following the 1926 bankruptcy of one of RCA's main competitors in the tube market, De Forest, the receiver in bankruptcy successfully sued RCA on the grounds that Clause Nine of its patent license contract, requiring all receiver licensees to buy tubes for their sets from RCA, violated the Clayton Act; a judgement which prompted further damage suits by independent tube markers. These were eventually settled in September 1931; RCA agreed to pay \$1 million to the Deforest Co., and smaller amounts to some other litigants, in return for their acceptance of a 5 percent license fee (which might later be reduced to 2.5 percent). ${ }^{65}$ Some tube manufacturers were said to welcome this, as a means of "stabilising" the industry - another example of how patent licensing could be used to meet the objectives of incumbent licensees, as well at the patent holder.

Moreover, a Federal Trade Commission investigation into RCA's restrictive practices, together with the courts' increasing willingness to view patent licensing as falling within the scope of anti-trust legislation, and the adverse publicity and damage to relationships with the radio trade (including retailers) that this generated, progressively undermined the viability of RCA's production monopoly strategy. ${ }^{66}$ RCA therefore reluctantly agreed to offer patent

\footnotetext{
${ }^{64}$ R. Sobel, RCA, New York 1986, p.84; W.R. Maclaurin, Invention and Innovation, New York 1949, pp.10718; Reich, Research, Patents, pp. 220-226.

65 Tube Suits Against RCA Settled by Cash and License Grants to 21 Claimants, Radio Retailing 66, October 1931; A.D. Chandler, Inventing the Electronic Century. The Epic Story of the Consumer Electronics and Computer Industries, New York 2001, p. 20.

${ }^{66}$ Maclaurin, Invention and Innovation, pp. 130-135; H.G.J. Aitken, The Continuous Wave. Technology and American Radio 1900-1932, Princeton NJ 1985, p. 501.
} 
licenses to receiver manufacturers from 1927, with royalties of 7.5 per cent of the set's wholesale value. Meanwhile it extended its patent monopoly by requiring licensees to offer it an option on any radio patents they developed - thus effectively creating a pool of all new radio patents.

RCA thus retained a strong long-term position in radio patents and tube manufacture, while also being a leading radio components manufacturer. These interests, together with broadcasting, that eventually became its most lucrative activity, became progressively more important than its role as a radio set manufacturer. Moreover, RCA retained its overall dominance of the radio sector. The U.S. Radio Manufacturers Association was widely regarded as a "tool" of RCA even in the late 1930s, given RCA control over the tube market and patents. ${ }^{67}$

However, there were clear limits to the extent of RCA control. The changed environment of the 1930s (depression, technological maturity, and the onset of market saturation) witnessed rising market shares for new entrants such as Philco, Zenith, and Emerson, that focused on cost reduction and intensive marketing rather than technical innovation. Philco in particular aggressively gained market share through under-cutting competitors' prices for radios of equivalent quality, becoming the dominant radio manufacturer of the 1930s. ${ }^{68} \mathrm{RCA}$ also proved powerless to stop the introduction of a new, cheaper, and more compact radio format, the "midget radio", which sold on price rather than quality. This format was strongly opposed by established manufacturers, but retailers seized on it as an easy sale in a Depression market weighed down with surplus stock. Meanwhile

\footnotetext{
${ }^{67}$ M.Graham, The threshold of the information age, pp. $137-175$ in: A.D. Chandler/ J.W. Cortada (Ed.), A Nation Transformed by Information, Oxford 2000, p. 163.

${ }^{68}$ Anonymous, Philco, in: Fortune Magazine 11, 1935, pp. 74-80 and pp.164-173.
} 
manufacturers were unable to take co-ordinated action against retailers who stocked midget sets, without overtly flouting anti-trust legislation.

America's strong anti-trust regime (by contemporary standards), in conjunction with some loopholes in RCA's control over fundamental patents, and its own production problems, had prevented RCA from establishing a monopoly position in radio set manufacture, or blocking the new midget radio format, which undermined the high-price, quality-based, competitive environment of the 1920s. This partly reflected the growing willingness of the courts to regard restrictive patent licensing as an anti-trust strategy (possibly influenced by the Federal Trade Commission's success in demonstrating the widespread use of fundamental patents and patent pools as an anti-trust devices in the early 1920s) ${ }^{69}$ Nevertheless RCA's first-mover advantages in entertainment radio, stemming from its control over fundamental patents, were considerable - enabling RCA to dominate the markets for radio tubes, patent licensing, and the increasingly lucrative radio broadcasting market for many years after it relinquished its claim to a radio set production monopoly.

\section{Radio patents in a low anti-trust environment: the United Kingdom}

Marconi Co. had already developed or acquired most of the fundamental British radio patents prior to the advent of entertainment radio, capitalising on its ability to block patents that built on its initial innovations to leverage good purchase terms for improvement patents. ${ }^{70}$ As a 1938 Marconi internal memorandum recalled, such agreements gave them rights to :

\footnotetext{
${ }^{69}$ Federal Trade Commission, Report on the House Furnishings Industry.

${ }^{70}$ Radcliffe Science Library, Oxford, Ms. Marconi [hereafter RSL, Marconi], 418, Marconi internal memorandum by W. Nicken, n.d., c. 1938, p.8.
} 
the great majority of patents of importance in the radio field in our territory. Without these we would have been greatly hampered in our business and probably involved in costly litigation over the use of fundamental patents. In order to avoid infringing less important and supplementary patents we should have had to spend money on research and development for this purpose... a particularly expensive method. ${ }^{71}$

For example, Armstrongs reaction patent, together with those for his superheterodyne and super-regenerative circuits, were acquired much more cheaply by Marconi than was the case for RCA, because these constituted developments on more basic patents that Marconi already owned. ${ }^{72}$ Such actions enabled Marconi to extent their dominance of UK radio patents beyond the lifetime of those patents that Marconi had actually generated through their own R\&D activities.

Buying out the entertainment rights of the other significant British patent-holder, British Thomson-Houston (BTH) consolidated Marconi's position, while it obtained British rights to the patents generated by the dominant firms in the other principal radio manufacturing countries through the deal whereby American Marconi was sold to RCA, together with subsequent negotiations involving the dominant firms in the other principal radio manufacturing nations (which also gave them local rights over Marconi's patents). These negotiations created an international patent cartel and, therefore, an international sales cartel - as foreign sets did not have British patents and were thus excluded from the home market (Marconi only granted patent licenses to UK firms). This in turn provided Marconi

\footnotetext{
${ }^{71}$ Ibid.

${ }^{72}$ Ibid.
} 
with great leeway to charge high royalty fees to British manufacturers, as they faced no significant threat from cheaper imported sets. ${ }^{73}$

Instead of seeking a production monopoly in radio, Marconi offered licenses to all British firms that agreed to comply with its conditions. This may have been influenced by the Post Office's opposition to a commercial monopoly over British entertainment radio, especially in the hands of Guglielmo Marconi (who was considered a foreigner and did not enjoy good relations with the British government). It thus made approval of entertainment broadcasting contingent on the development of a framework which would avoid this. ${ }^{74}$ This proved fortuitous for Marconi Co., as its performance as a radio set manufacturer was even worse than that of RCA, incurring heavy cumulative losses owing to basic managerial errors. ${ }^{75}$ In 1928 Marconi ceased radio manufacture, selling its interests in receiver and tube production (and half the royalties of its patent pool) to EMI.

The problem faced by Marconi in extracting the maximum 'rent' from its royalty monopoly has received significant discussion in the economics of vertical integration usually modelled in terms of a monopolist supplying a component to a potentially competitive market of assembly manufacturers that might find ways of partially substituting it with cheaper components not controlled by the monopolist. ${ }^{76}$ To prevent this, the

\footnotetext{
${ }^{73}$ Maclaurin, Invention and Innovation, p. 107; Sobel, RCA, pp. 21-35; RSL, Marconi, 418, Marconi internal memorandum by W. Nicken, n.d., c. 1938, pp. 6-7.

${ }^{74}$ Michele Hilmes, Networked Nations. A Transnational History of British and American Broadcasting, London 2012, pp. 38-39.

${ }^{75}$ See Scott, Market Makers, p. 143.

${ }^{76}$ J.M. Vernon / P.A Gordon, Profitability of Monopoly by Vertical Integration, in: Journal of Political Economy 79, 1971, pp. 924-925; R. Schmalensee, A Note on the Theory of Vertical Integration, in: Journal of Political Economy 81, 1973, pp. 442-449; F.R.Warren-Boulton, Vertical control with variable proportions, in: Journal of Political Economy 82, 1974, pp. 783-802.
} 
monopolist can either extend its monopoly into direct assembly operations (as RCA attempted to do) or insist, as a condition of patenting, that no such substitution can take place. The latter strategy is regarded as more difficult, as it entails considerable monitoring and enforcement costs. Meanwhile costly innovations aimed at reducing the use of the monopoly input are predicted to lower the efficiency of the overall value chain. ${ }^{77}$

Marconi tried to block innovation around its patents using a packaging license strategy. Manufacturers were obliged to license all Marconi’s 13 key patents, despite it being possible to produce a viable radio with only two of them. ${ }^{78}$ Licenses were granted to all British manufacturers who accepted Marconi's conditions, with a standard royalty of $12 \mathrm{~s} 6 \mathrm{~d}$ per tube-socket (taken as a proxy for the set's value). ${ }^{79}$ From the advent of broadcasting in Britain in 1922, to around the end of 1926, Marconi had issued some 2,000 licenses to radio manufacturers. ${ }^{80}$

Marconi's licensing strategy proved very profitable. At the end of December 1920 its patents and patent rights were valued (at cost) at $£ 280,417 .{ }^{81}$ The launch of the $\mathrm{BBC}$ led to

${ }^{77}$ O.E. Williamson, Markets and Hierarchies. Analysis and Antitrust Implications, New York 1975, p. 85;

Warren-Boulton, 'Vertical Control'.

${ }^{78}$ R.J. Gilbert/M.L. Katz, Should Good Patents come in Small Packages? A Welfare Analysis of Intellectual Property Bundling, in: Journal of Industrial Organization 24, 2006, pp. 931-52; W.J. Adams / J. L. Yellen, Commodity Bundling and the Burden of Monopoly, in: Quarterly Journal of Economics 90, 1976, pp. 475-98.

${ }^{79}$ P.R. Morris, A Review of the Development of the British Thermionic Valve Industry, in: Transactions of the Newcomen Society, for 1993-94, 1994, p. 59. Discounts were offered to some large firms, see S.G. Sturmey, The Economic Development of Radio, London 1958, pp. 45 and 215-19. ${ }^{80}$ RSL, Marconi 588. Report on investigation of Marconi Wireless Telegraph Co. Ltd by Price Waterhouse \& Co. and Cooper Brothers \& Co., 20 $0^{\text {th }}$ January 1927, p. 63.

${ }^{81}$ RSL, Marconi, 594, Marconi Wireless Telegraph Company.... Shares in associated companies and patent rights. As at $31^{\text {st }}$ December 1920 , n.d., c. 1921. 
Marconi's royalty income jumping from $£ 11,470$ in 1922 to $£ 60,861$ in 1923 , while data for subsequent years (restricted to Marconi radio patent pool receipts) show further rapid growth up to 1927, as shown in Figure 2. However, radio manufacturers found Marconi's terms particularly onerous and sought ways to minimise patent costs. While it was impossible to directly innovate around Marconi's patents, the form of the Maroni license - based on the number of tubes per set - enabled indirect innovation to minimise patent royalties by using fewer tubes to achieve the same functionality. Tube manufacturers first focused on increasing the amplification factor of each amplifying tube, then, in 1930s, began to develop multifunctional tubes. ${ }^{82}$

\section{[Figure 2 near here]}

Such tubes were more complex and expensive to produce, raising prices substantially compared to the simpler, interchangeable, American tubes, which did not have to be manufactured to such close tolerances and were thus considerably cheaper. ${ }^{83}$ However, given that set-makers saved more money on royalties than they paid in higher tube costs, overall costs were reduced. ${ }^{84}$ This contributed to an Anglo-American productivity gap in radio equipment that was large, even compared to other manufacturing sectors, though the British industry was shielded by formidable import barriers (exclusive patent rights and tariff protection). ${ }^{85}$ The premium on tubes with larger numbers of functions constituted a pathdependent process of technical change and, while the 'lock-in’ imposed by this process

\footnotetext{
${ }^{82}$ Morris, Review of the development, pp. 60-61.

${ }^{83}$ Bodleian, Bussey, Box 18, G.R.M. Garratt, The Mullard story. A biographgy of S.R. Mullard and a history of Mullard Limited, unpublished manuscript. Part 5, pp. 10-11.

${ }^{84}$ See $P$. Scott, The origins of the Anglo-American 'productivity gap' in electronics: the British and American interwar radio equipment industries (University of Reading Discussion Paper, 2011).

${ }^{85}$ Scott, Market Makers, pp. 136-137.
} 
proved relatively weak, the complex, high cost, technical path of British tubes was only gradually undermined once the fundamental patents expired. Even in 1937 average unit values for exported British tubes were 220 percent higher than for tubes exported from the U.S.A. over $1935-7 .^{86}$

Marconi's licensing strategy damaged relations with the radio equipment makers' trade association, the (UK) Radio Manufacturers Association (hereafter RMA). British royalties were substantially higher than for other major radio manufacturing nations and encouraged home construction of kit radios, or manufacture by firms sufficiently small to evade royalties. ${ }^{87}$ Radio manufacturers also resented the fact that being forced to innovate around Marconi's patent system markedly increased their production costs. Standard royalties on a three tube battery set rose from 7.5 percent of the average retail price in 1924 to 11.0 percent in 1928. As the 'retail price' data on which this estimate is based include essentials such as valves, batteries, and speakers - typically sold separately at this time - and retail prices were approximately double factory gate values, the impact on manufacturers' costs was well in excess of 20 percent by $1928 .^{88}$

RMA lobbied for a much lower royalty, levied on the net selling price of the radio, at a basic rate of 5 per cent. Marconi's rejection of any reduction led to a test case, after the Brownie Co. (whose two valve set was doubled in price by the Marconi royalty) approached the Comptroller-General of Patents in 1928 for a compulsory license for two of Marconi's 13

\footnotetext{
${ }^{86}$ TNA, BT 64/279, Radio valves, draft memorandum, n.d. (c. March 1946); Royal Mail Archives, London, POST 89/37, Ullswater Committeee paper No. 126, memorandum by Sir John Reith on broadcasting and the wireless trade, $19^{\text {th }}$ Sept. 1936; World wireless trade. Some highlights of the export and import sides, in: Wireless \& Electrical Trader, 22 $2^{\text {nd }}$ October 1938, p. 115.

${ }^{87}$ Sturmey, Economic Development, p. 217.

${ }^{88}$ Scott, Market Makers, pp. 142-148.
} 
patents. ${ }^{89}$ Brownie alleged infringement of the Patents and Design Act, 1919, emphasising that Marconi refused to grant separate licenses for particular patents and levied royalties on all valve-sockets, even those that did not infringe Marconi patents.

Judgement in the Brownie case was in line with Britain's "liberal-conservative" political economy, prioritising private property rights over considerations of equity or competiton. In August 1928 the Comptroller-General found that Marconi's royalties were unreasonable, but allowed Marconi to retain its package license system. Marconi then successfully appealed at the High Court, where Mr Justice Luxmoore ruled that Marconi was, 'entitled to monopoly rights flowing from the ownership of patents it had acquired.90

Louis Kaplow’s "ratio test" evaluates the conflicting social welfare benefits of intellectual property rights, and unrestricted competition, using the ratio between the reward the patentee receives when permitted to use a particular restrictive practice and the monopoly loss resulting from such exploitation (licensing practices which generate higher ratios being preferred). ${ }^{91}$ Viewed from this perspective, RCA's licensing system was clearly superior to Marconi's, as Marconi's royalties were both markedly higher and encouraged expensive and inefficient innovation around their patents - a problem recognised in the intellectual property literature (justifying RCA's practice of patent charges based on the price of the end product, even when not all components are subject to the patents). ${ }^{92}$

The difference in cost structures is illustrated by comparison of the value chains for typical UK and US household receivers in 1928, shown in Table 3. The British figure for manufacturing includes manufacturers' advertising, though this is unlikely to significantly

\footnotetext{
${ }^{89}$ Sturmey, Economic Development, pp. 216-18.

90 The Times, $19^{\text {th }}$ June $1929,5$.

${ }^{91}$ Kaplow / Carrier, Unravelling the Patent-antitrust, pp. 797-798.

${ }^{92}$ Kaplow, The patent-antitrust Intersection, pp. 1883-1884.
} 
distort the comparison. In the UK patents accounted for 11 per cent of the total retail price, compared to only 4.1 percent in the USA. British tubes also comprised a significantly larger proportion of total set value, reflecting the bias towards fewer, more complex, tubes arising from Britain's patent system. Extra costs attributable to patents and innovation around them thus amount to around 10 per cent of the retail price according to this measure.

\section{[Table 3 near here]}

Both the British and American radio sectors developed similarly fragmented structures, owing to very limited scale economies in an industry characterised by simple assembly methods, highly unpredictable demand, and rapid technical obsolescence. ${ }^{93}$ As Figure 3 shows, cumulative market shares (of unit sales) for the largest firms in each country were very similar. However, the welfare effects of the U.S. system were markedly superior. Effective anti-trust legislation increased the bargaining position of licensees and prevented the blocking of lower-cost radio formats, such as the midget radio. Midget sets were largely responsible for a steep fall in average U.S. radio retail prices during the 1930s, from $\$ 133$ in 1929 to only $\$ 37$ in 1934 , with some midget radios selling for less than $\$ 10$ by the late 1930s. ${ }^{94}$ This episode of destructive "architectural innovation" (changing the configuration of the components of a product, rather than the components themselves) had undermined the established basis of competitive advantage in the U.S. industry, with three of the four largest

\footnotetext{
${ }^{93}$ See P. Scott, When Innovation Becomes Inefficient: Reexamining Britain's Radio Industry, in: Business History Review 88, 2014, pp. 497-521, pp. 502-507.

${ }^{94}$ P. Scott, The Market Makers, pp. 118 and 122-123. Figures for 1929 and 1934 are exclusive of tubes (which were typically purchased separately at this time).
} 
American set-makers in 1929 no longer being significant manufacturers by the late 1930 s. ${ }^{95}$ However, this format was supressed in Britain by a trade boycott (which would have been illegal in the USA), together with vigorous patent litigation against importers of American midget radios. ${ }^{96}$ Britain nevertheless achieved rapid diffusion of domestic radios compared to most other nations, though that was largely due to the high-quality national radio programming provided by the BBC.

\section{[Figure 3 near here]}

\section{Conclusions}

These four case-studies highlight the considerable potential for adverse welfare impacts from strong patent regimes, in the absence of strong anti-trust regimes. Britain constituted an extreme case of a strong patent, weak anti-trust, environment. While most countries rejected the carbonised filament patent, Britain was prepared to grant it, resulting in a major rise in the costs of electric lighting and a reduction in its diffusion - which delayed the spread of electricity supply, in turn retarding the diffusion of electrical machinery and appliances for domestic, commercial, and industrial use. Similarly in radio the cheaper midget format was supressed by a British trade boycott underpinned by patent litigation against non-complaint manufacturers or their retailers. This forms part of a broader cluster of negative technological and economic consequences arising from Britain's liberalconservative political economy of non-interference in private business (also demonstrated, for example, in a long delay in setting a mandatory standard voltage for mains electricity

\footnotetext{
${ }^{95}$ Ibid, p. 122. For architectural innovation, see $R$ M. Henderson / K.B. Clark, Architectural Innovation: the Reconfiguration of Existing Product Technologies and the Failure of Established Firms, in: Administrative Science Quarterly 35, 1990, pp. 9-30.

${ }^{96}$ P. Scott, The Market Makers, pp. 153-5.
} 
supply, compared to the USA), which significantly contributed to Britain's loss of technological advantage during the second industrial revolution.

Prior to 1914 the U.S. also had an anti-trust regime which was largely ineffective in addressing monopolies and cartels created through the control of fundamental patents. Even in cases where the patent-holder did not wish to create a production monopoly, established firms in the sector could negotiate restrictive licensing arrangements designed to block entry - again raising prices and potentially slowing diffusion. The Kenney patent provides an illustration of this process, confirming the predictions of higher prices and 'rents'. The impact on product diffusion is unclear, as high profits led the sector's leading firms to invest heavily in direct salesforces - a particularly effective, but expensive, distribution method for new consumer durables. ${ }^{97}$

For technologies subject to cumulative innovation, the impact of patent restrictions per se appears less negative. As the U.S. and U.K radio cases have shown, the need to negotiate patent rights to basic or improvement innovations led to a system of international patent pools, where all the major radio-producing nations had access to each other's patents. However, the absence of a strong anti-trust environment to temper the monopoly features of patent pools is again shown to produce markedly inferior outcomes. Britain's patent license system involved much higher rents than the U.S. system, while also leading manufacturers to undertake expensive innovation to minimise patent costs, which was successful, but nevertheless substantially raised production costs. Meanwhile the persistent production problems experienced by both the RCA combine's, and Marconi's, direct radio manufacturing operations highlight the strong welfare losses that would have occurred if each firm had been allowed to act as a production monopolist.

\footnotetext{
${ }^{97}$ Ibid, pp. 207-232.
} 
More generally, our research illustrates the potential for industry control through patents and the importance of examining this not only in terms of patenting law and litigation, but the interactions between the patent holder, industry incumbents, and new entrants. Patent licensing could be used not only to generate high rents, but to limit entry to the industry, tie component purchases to patent access, supress new product innovations (such as the midget radio) and impose price-fixing and market-sharing agreements. Moreover, even if the patent holder was uncertain about its legal position it was still possible to leverage a claim to a fundamental patent, by harassing manufacturers - or their distributors and retailers - with continued threats of litigation. ${ }^{98}$ Our research thus highlights the need for the monopoly power characteristics of patents to be tempered by effective legislation, not only to prevent monopoly production, but monopoly power, which can have strong negative welfare effects even in situations where licenses are granted to all firms that will accept the monopolist's restrictive conditions.

\footnotetext{
${ }^{98}$ Price-fixing and harassment of retailers with threats of litigation were tactics used, for example, in the U.S. washing machine sector, see U.S. Federal Trade Commission, Report of the Federal Trade Commission on the House Furnnishing Industry, pp. xxi \& 26-30.
} 
Table 1: Comparison of Net Prices Quoted to a Corporation for Standard Vacuum Wire Filament Lamps, High Volt (25 and 50 C.P.) by the Tungsten Lamp Association and five independent manufacturers

\begin{tabular}{|c|c|c|c|c|c|c|c|c|c|c|c|c|c|c|}
\hline & \multicolumn{4}{|c|}{ Association } & \multicolumn{10}{|c|}{ Non-Association } \\
\hline & \multicolumn{2}{|c|}{$\begin{array}{l}\text { Retail price } \\
\text { list }\end{array}$} & \multicolumn{2}{|c|}{ Net Price Quoted } & \multicolumn{2}{|c|}{$\mathbf{A}$} & \multicolumn{2}{|c|}{ B } & \multicolumn{2}{|c|}{$\mathrm{C}$} & \multicolumn{2}{|c|}{$\mathbf{D}$} & \multicolumn{2}{|c|}{$\mathbf{E}$} \\
\hline & $\mathrm{s}$ & $\mathrm{d}$ & $\mathrm{S}$ & $\mathrm{d}$ & $\mathrm{S}$ & d & $\mathrm{S}$ & $\mathrm{d}$ & $\mathrm{s}$ & $\mathrm{d}$ & $\mathrm{S}$ & $\mathrm{d}$ & $\mathrm{S}$ & $\mathrm{d}$ \\
\hline 1914 & 2 & 8 & 1 & 7.48 & 1 & 3.75 & 1 & 2 & 1 & 4 & - & - & - & - \\
\hline 1915 & 2 & 8 & 1 & 9.76 & 1 & 3 & 1 & 2 & 1 & 4 & - & - & - & - \\
\hline 1916 & 2 & 8 & 1 & 6.94 & 1 & 3 & 1 & 1.6 & 1 & 4 & - & - & - & - \\
\hline 1917 & 3 & 0 & 1 & 5.52 & 1 & 3 & 1 & 1.8 & 1 & 1 & - & - & - & - \\
\hline 1918 & 3 & 6 & 2 & 6.24 & - & - & 2 & 1.2 & - & - & - & - & - & - \\
\hline 1919 & 3 & 6 & 2 & 3.46 & - & - & 2 & 1 & 2 & 1 & 1 & 11 & 1 & $11^{1 / 2}$ \\
\hline Jan., 1920 & 3 & 6 & 2 & 3.46 & - & - & 2 & 1 & 1 & 11.8 & 1 & 11 & 2 & 1 \\
\hline
\end{tabular}

Source: Profiteering Act, 1919, Findings and Decisions of a Sub-committee appointed by the Standing Committee on Trusts, to Enquire into the Existence of any Trust of Trade Combination in the Electric Lamp Industry, 1920 
Table 2: Costs and profits for eleven vacuum cleaner manufacturers providing data to the Federal Trade Commission for 1920 and 1921

\begin{tabular}{|c|c|c|c|c|c|c|c|c|c|c|}
\hline \multirow{2}{*}{\begin{tabular}{|r} 
Investment size \\
\\
\\
1920 \\
\end{tabular}} & \multirow{2}{*}{$\begin{array}{l}\text { No. of } \\
\text { firms } \\
\end{array}$} & \multirow{2}{*}{$\begin{array}{l}\text { Average } \\
\text { net sales }\end{array}$} & \multicolumn{4}{|c|}{ Percentage of net sales accounted for by: } & \multirow[b]{2}{*}{$\begin{array}{l}\text { Profit on } \\
\text { goods } \\
\text { sold } \\
\end{array}$} & \multirow[b]{2}{*}{$\begin{array}{c}\text { Net } \\
\text { deduct- } \\
\text { ions }\end{array}$} & \multirow[b]{2}{*}{$\begin{array}{l}\text { Net } \\
\text { profit }\end{array}$} & \multirow[b]{2}{*}{ Total } \\
\hline & & & $\begin{array}{c}\text { Factory } \\
\text { cost of } \\
\text { goods }\end{array}$ & $\begin{array}{l}\text { Selling } \\
\text { expense }\end{array}$ & $\begin{array}{l}\text { General } \\
\text { admin. } \\
\text { expense }\end{array}$ & $\begin{array}{l}\text { Total } \\
\text { costs }\end{array}$ & & & & \\
\hline Over \$1milion & 3 & $6,288,643$ & 52.9 & 25.7 & 8.3 & 86.9 & 13.1 & 1.2 & 11.9 & 100.0 \\
\hline$\$ 500,000-\$ 1$ million & 4 & $3,087,113$ & 72.3 & 11.9 & 6.4 & 90.6 & 9.4 & 2.9 & 6.5 & 100.0 \\
\hline Under $\$ 500,000$ & 4 & 987,374 & 74.0 & 6.3 & 6.0 & 86.3 & 13.7 & 1.7 & 12.0 & 100.0 \\
\hline Total & 11 & $3,196,716$ & 62.1 & 18.7 & 7.4 & 88.1 & 11.9 & 1.9 & 10.0 & 100.0 \\
\hline \multicolumn{11}{|l|}{1921} \\
\hline Over \$1milion & 3 & $3,631,861$ & 45.1 & 29.4 & 12.7 & 87.1 & 12.9 & 0.6 & 12.2 & 100.0 \\
\hline$\$ 500,000-\$ 1$ million & 4 & $2,337,044$ & 65.9 & 16.2 & 8.0 & 90.1 & 9.9 & 3.4 & 6.5 & 100.0 \\
\hline Under $\$ 500,000$ & 4 & 594,496 & 66.0 & 6.6 & 9.2 & 81.8 & 18.2 & 3.7 & 14.6 & 100.0 \\
\hline Total & 11 & $2,056,522$ & 55.9 & 21.6 & 10.4 & 87.8 & 12.2 & 2.1 & 10.1 & 100.0 \\
\hline
\end{tabular}

Source: Federal Trade Commission, Report on the House Furnishings Industry. Volume III: Kitchen Furnishings and Domestic Appliances,

Washington 1925, p. 305. 
Table 3: The value chains for typical American, and British, radio sets in 1928 (percent of retail price).

\begin{tabular}{|l|r|r|}
\hline Stages of value chain & USA & UK \\
\hline Patents & 4.1 & 11 \\
\hline Manufacture* & 31.9 & 32 \\
\hline Tubes & 9.0 & 12 \\
\hline Advertising \& distribution & 55.0 & 45 \\
\hline Total & 100 & 100 \\
\hline
\end{tabular}

Sources and notes: see Peter Scott, The Market Makers. Creating Mass Markets for Consumer Durables in Inter-war Britain, Oxford 2017, pp. 111 and 159.

* UK figure includes manufacturers' advertising. 
Figure 1: Number of producers of incandescent Lamps, in Britain, the USA, France, and Germany, 1889-1896

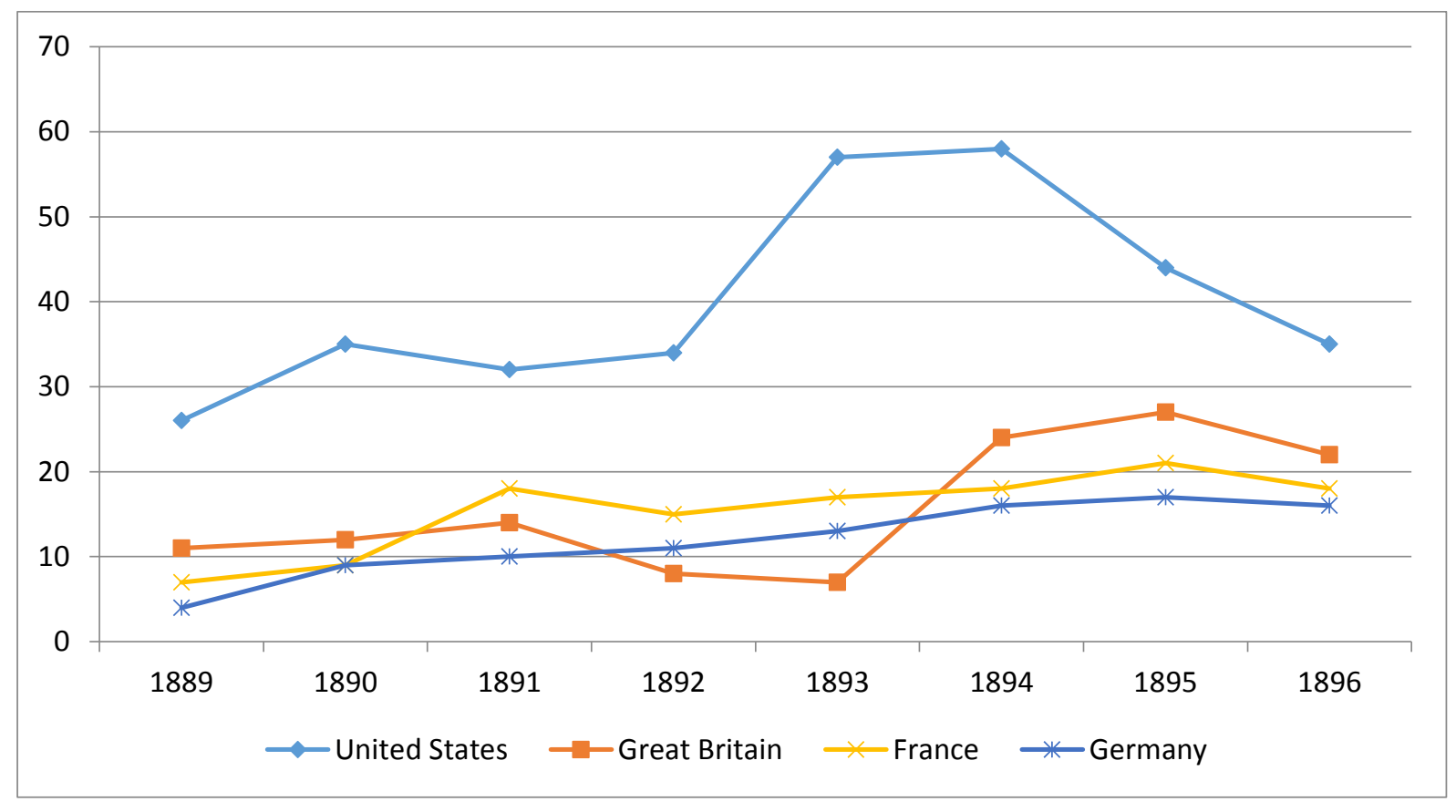

Source: A. A. Bright, The Electric-Lamp Industry. Technological Change and Economic Development from 1800 to 1947, New York 1949 , p. 487. 
Figure 2: Gross revenue patent pool revenue for radio broadcast receivers and related apparatus, 1923-32

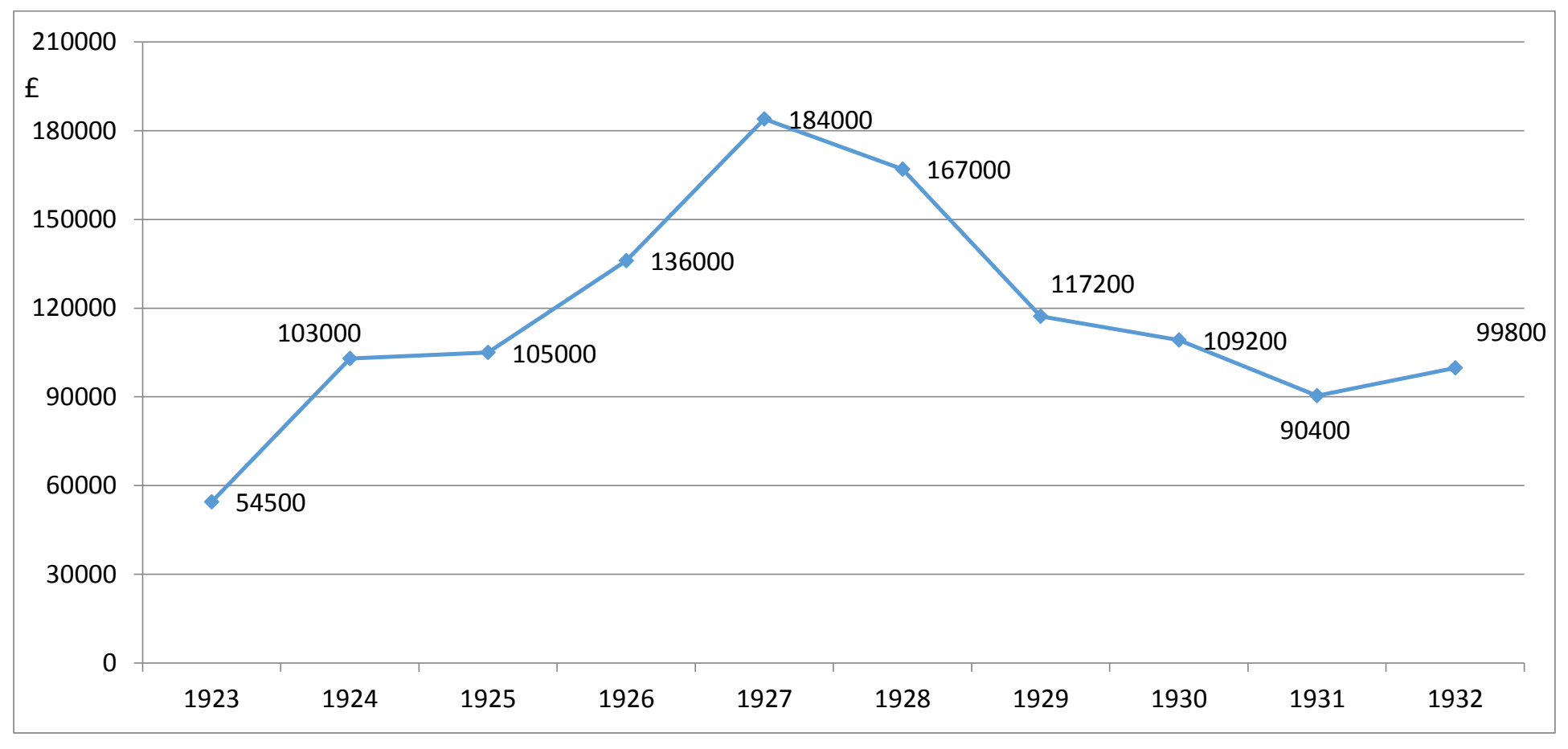

Source, Marconi 418. Marconi undated internal memorandum, n.d., c. 1938, by W. Nicken.

Notes: before deduction of management expenses, bad debts, etc. From 1929 onwards theincome was divided equally between Marconi and EMI. 
Figure 3: Cumulative market shares (units sold) for the largest radio manufacturers in the USA (1940) and UK (1938)

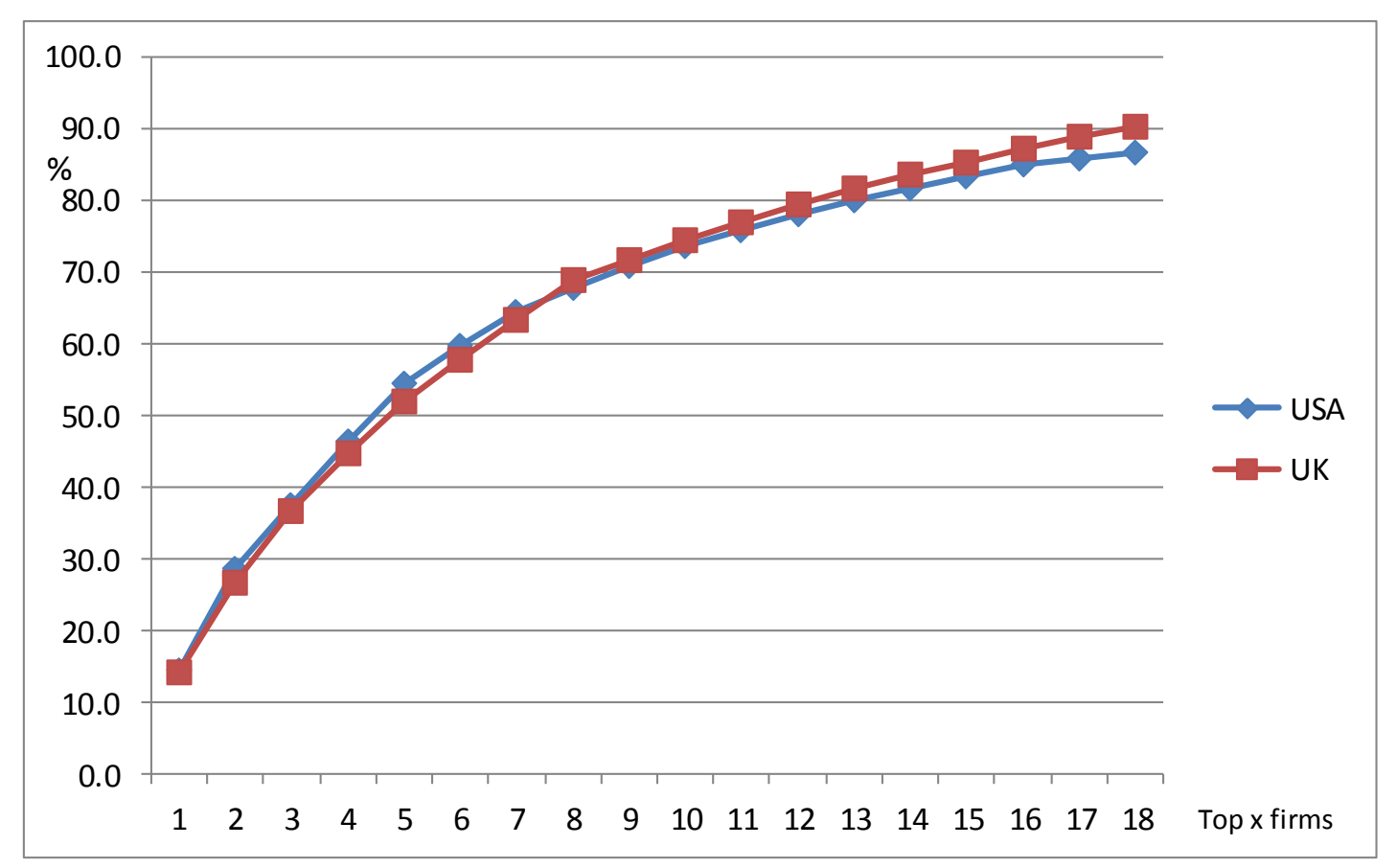

Sources: USA, W.R. Maclauren, Invention \& Innovation in the Radio Industry, New York 1949, p. 146; UK - MMSI, Ferranti collection, 1996.10/1/7/409, printed statement of R.M.A. radio data for year ending 31st Dec. 1938, n.d., c. 1939. 